DOI 10.37882/2500-3682.2021.10.16

\title{
УСПЕШНОСТЬ ОВЛАДЕНИЯ ИНОСТРАННЫМ ЯЗЫКОМ В УСЛОВИЯХ УНИВЕРСИТЕТСКОГО ОБРАЗОВАНИЯ
}

\section{SUCCESSFUL FOREIGN LANGUAGE LEARNING IN THE CONDITIONS OF UNIVERSITY EDUCATION}

\section{N. Shcherbakova \\ Kh. Khayrova}

Summary: The article is devoted to the problem of the development of the success of mastering a foreign language by students in the process of studying at a university. The role of a foreign language is increasing in connection with the development of economic ties, with the internationalization of public diplomacy. Being a cognitive activity, mastering a foreign language is subject to the action of universal factors that determine the success or failure of this type of activity, both objective (learning conditions) and subjective (mental cognitive processes, affective sphere, volitional processes, abilities, needs and motives, character traits, characteristics temperament).

The article identifies the factors of the success of students' professional training in mastering a foreign language. The article analyzes research data on the relationship between success in a foreign language and student's personal qualities.

Keywords: success, success, successful learning, personality traits, mastering a foreign language, student age, higher education.
Щербакова Наталья Евгеньевна

к.n.н., доцент, ФГБОУ ВО «Пензенский государственный университет»

stenyakova-n@mail.ru

Хайрова Халида Жаферовна

к.n.н., доцент, ФГБОУ ВО «Пензенский государственный

университет»

halida.tat@yandex.ru

Аннотация: Статья посвящена проблеме развития успешности овладения иностранным языком студентами в процессе обучения в вузе. Роль иностранного языка возрастает в связи с развитием экономических связей, с интернационализацией народной дипломатии. Являясь познавательной деятельностью, овладение иностранным языком подвержено действию универсальных факторов, определяющих успешность или неуспешность данного вида деятельности как объективных (условия обучения), так и субъективных (психических познавательных процессов, аффективной сферы, волевых процессов, способностей, потребностей и мотивов, черт характера, особенностей темперамента).

В статье выявлены факторы успешности профессиональной подготовки студентов в овладении иностранным языком. Анализируются данные исследования связи успешности в иностранном языке и личностных качеств студента.

Ключевые слова: успех, успешность, успешное обучение, качества личности, овладение иностранным языком, студенческий возраст, высшее образование.

ситетского образования связана с такими факторами, как уровень довузовской подготовки, индивидуальные способности, умение планировать и контролировать свою учебную деятельность, уровень квалификации преподавательского состава вуза. К другой группе факторов традиционно относят состояние здоровья студента, материальное положение его семьи и др. [1].

Мы считаем, что для успешного овладения иностранным языком необходимы следующие качества личности: волевые качества, а именно волевая саморегуляция и волевой контроль (Н.С. Назаренко [2]); специальные способности, например, сенсорные, к которым относится фонематический слух; креативность; беглость мышления; гибкость мышления; социальный интеллект; положительная внутренняя учебная мотивация; адекватная самооценка; общий уровень интеллекта; познавательнокоммуникативная потребность в изучении иностранного языка (И.А. Зимняя[3]).

Н.М. Симонова дифференцирует четыре мотивационные ориентации при усвоении иностранного языка в вузе: мотивация на процесс учебной деятельности; моти-

Успешность обучения студентов в условиях универ- 
вация на результат учебной деятельности; мотивация на оценку; мотивация на избегание неприятностей. Автор утверждает динамический характер структуры учебной мотивации, варьирование ее компонентов в зависимости от условий обучения (типа вуза, сетки часов, особенностей программ, целевых установок, года обучения) [4].

На основе вышеизложенного в своем исследовании мы предположили, что студенты, обладающие такими качествами как общительность, высокий интеллект, гибкость мышления, высокий самоконтроль, адекватная самооценка, а также внутренней мотивацией наиболее успешны в овладении иностранным языком.

Для подтверждения данного предположения было предложено студентам пройти анкетирование, на основе которого выявлялись такие показатели, как: является ли студент успешным, имеется ли интерес к предмету, мотивация и цели изучения иностранного языка, а также какие трудности он испытывает в овладении иностранным языком.

В исследовании приняли участие 60 студентов первых-вторых курсов Педагогического института им. В.Г. Белинского ФГБОУ ВО «Пензенский государственный университет».

Результаты анкетирования показали, что 80\% опрошенных имеют оценки «4» и «5» по иностранному языку, что говорит об их успешности, также 70\% человек отметили, что им нравится его изучать, т.е. они заинтересованы в обучении и хотели бы продолжить обучение в дальнейшем. Остальные $20 \%$ - имеют оценку «3», также можно отметить, что 15\% опрошенных не заинтересованы в дальнейшем обучении иностранному языку, они не видят в нем необходимости, кроме как для перехода на следующий курс. В качестве целей 45\% респондентов отметили, что язык им необходим в первую очередь для саморазвития и самосовершенствования; 40\% студентов - необходимость языка в общении с иностранцами и $30 \%$ отметили важность языка для путешествий; еще для 5\% опрошенных главная цель изучения языка - просмотр фильмов и чтение книг в оригинале. В качестве трудностей, которые возникают при изучении иностранного языка студенты отметили: $20 \%$ опрошенных испытывают трудности, связанные с произношением, с усвоением фонетических основ; 15\% опрошенных - с изучением грамматики и еще $15 \%$ испытывают трудность с запоминанием слов, вследствие чего обладают малым словарным запасом. Также 10\% студентов отметили нехватку времени, как препятствие в овладении языком и 5\% - отсутствии практического применения из-за чего возникают проблемы с акцентом. Остальные 35\% респондентов трудностей в овладении иностранным языком не испытывают.
Затем с помощью методики многофакторного исследования личности Р. Кеттелла было проведено исследование для определения выраженности определенных факторов личности, которые, предположительно, могут влиять на успешность студентов в овладении иностранным языком, а именно: общительность - замкнутость (фактор А: Общительность), высокий интеллект - низкий интеллект (фактор В: Интеллектуальность), гибкость мышления - ригидность мышления (фактор Q1: Радикализм), высокий самоконтроль - низкий самоконтроль (фактор Q3: Дисциплинированность).

По фактору «Общительность» 15\% студентов обладают высоким уровнем выраженности этого свойства личности, что говорит об их открытости, легкости в общении, эмоциональности, разговорчивости, импульсивности, любят работать в коллективе, часто берут на себя роль организатора; большинство опрошенных студентов, а именно 60\% обладают средним уровнем выраженности этого свойства; $25 \%$ имеют низкие показатели, что говорит об их замкнутости, такие люди чаще обособлены, конфликтны, холодноваты, нет эмоциональной живости в общении, молчаливы, несколько педантичны и более эффективны, когда работают в одиночку.

По фактору «Интеллектуальность» 35\% опрошенных студентов обладают высоким интеллектуальным потенциалом, 60\% обладают средним уровнем выраженности этого свойства; 5\% студентов имеют низкий уровень.

По фактору «Радикализм» 30\% опрошенных студентов обладают высоким уровнем гибкости мышления. Большинство опрошенных студентов, а именно 65\% обладают средним уровнем выраженности этого свойства и 5\% - низким уровнем, что говорит о консерватизме, ригидности мышления, боязни всего нового.

По фактору «Дисциплинированность» $10 \%$ опрошенных студентов обладают высоким уровнем самоконтроля, 80\% обладают средним уровнем выраженности этого свойства и 10\% - обладают низким самоконтролем.

По методике исследования самооценки личности С.А.Будасси большинство студентов (55 \%) обладают средней адекватной самооценкой, что говорит о наличии положительной связи между Я-реальным и Я-идеальным.

Результаты применения методики «Опросник направленности учебной мотивации» Т.Д. Дубовицкой следующие: высоким уровнем мотивации обладают 75\% студентов, что говорит об их увлеченности предметом иностранного языка, их деятельность направлена на сам процесс, сама по себе работа, овладение содержанием данного предмета выступает одновременно и мотивом, и целью; 40\% студентов обладают ярко-выраженной 
внутренней мотивацией, что говорит о том, что они наиболее заинтересованы изучением иностранного языка и для них на данный момент это актуально; низкий уровень внутренней мотивации имеют 25\%, у данных студентов мотивация внешняя, т.е. их деятельность больше направлена на результат, нежели чем на сам процесс, она связана с какими-либо внешними обстоятельствами, требующими дополнительных стимулов.

Высоким уровнем мотивации на достижение успеха по методике диагностики личности на мотивацию к успеху и избеганию неудач Т. Элерса обладают 10\% опрошенных студентов. Средний уровень мотивации на достижение успеха имеют также 40\%, данным студентам необходимо несколько активизировать себя, чтобы быть преуспевающим в данной области, работать над собой, вырабатывать уверенность и целеустремленность; $10 \%$ студентов обладают низким уровнем мотивации на успех, они проявляют неуверенность в себе, тяготятся выполняемой работой.

Полученные результаты были подвергнуты математико-статистической обработке с целью обнаружения достоверной связи успешности в иностранном языке и личностных качеств студента с помощью t-критерия Стьюдента.
Из результатов корреляционного анализа обнаруживается наличие большого количества взаимосвязей между различными параметрами. А именно, были выявлены положительные корреляции успешности студентов с показателями мотивации ( $t_{\text {эмп }}=3.2$ ), между успешностью студентов и фактором «Интеллектуальность» $\left(t_{\text {эмп }}=3.1\right)$, между успешностью студентов и фактором

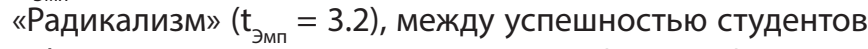

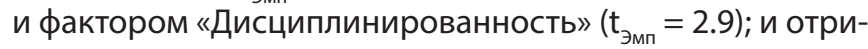
цательные корреляции между успешностью студентов и фактором «Общительность» $\left(\mathrm{t}_{\ni \text { мп }}=0.2\right)$, между успешностью студентов и показателями самооценки $\left(\mathrm{t}_{\text {эмп }}=0.7\right)$.

Мы выявили и отрицательные корреляционные связи между успешными и неуспешными группами студентов по факторам «Общительность», а также в отношении самооценки. Такие результаты, по нашему мнению, объясняются недостаточностью выборки, и дальнейшие исследования могут выявить более существенные различия.

В дальнейшем необходимо проработать и апробировать модель развития успешности овладения иностранным языком в условиях вузовского образования, а также выявить педагогические условия успешности в овладении иностранным языком.

ЛИТЕРАТУРА

1. Смирнов С.Д. Психологические факторы успешной учебы студентов вуза [Электронный ресурс]. - Режим доступа: http://www.psy.msu.ru/science/public/ smirnov/students.html.

2. Назаренко Н.С. Психологические детерминанты эффективности овладения иностранным языком в вузе: Автореф. дисс. . . канд.псих.наук: 19.00.07. М.: Московский гос. пед. ин-т, 1986. - 16 с.

3. Зимняя И.А. Психология обучения неродному языку. - М.: Русский язык, 1989. - 219с.

4. Симонова Н.М. Экспериментальное исследование структуры мотивации при усвоении иностранного языка в вузе: Автореф. дисс. . . канд.псих.наук: 19.00.07. - Московский гос. пед. ин-т, 1982. - 15 с.

( Щербакова Наталья Евгеньевна (stenyakova-n@mail.ru), Хайрова Халида Жаферовна (halida.tat@yandex.ru).

Журнал «Современная наука: актуальные проблемы теории и практики» 